Yuliya Shatylo, PhD, Assoc. Prof.,

Olexandra Gromova, student

National Aviation University, Kyiv, Ukraine

\title{
DEVELOPMENT OF FUNDRAISING AS A TECHNOLOGY OF SOCIAL WORK IN UKRAINE
}

In the article the authors cover a theoretical analysis of scientific literature on the problems of using fundraising as a technology of social work in modern Ukraine. Non-profit organizations act as social intermediaries-implementers of social ideas and programs. They operate between the state, commercial firms and citizens. It is important to develop a comprehensive economy and the state, both for business and society.

Fundraising area is a new field of activity for our country. For attraction of resources of sponsors and donors, there are first-rate specialists who are able to replenish the budget of public organizations. The introduction and use of fundraising technology will expand the financial capabilities of social institutions and, consequently, increase the efficiency of their functioning. The dynamics of fundraising development in Ukraine is fast and efficient. An important factor in accelerating this process is the highly skilled training of specialists in this field of activity, which will have the appropriate knowledge, skills, skills and competencies.

Fundraising is an almost new area of activity for our country. It has been developed in the US and Europe, where a diverse system of benefits and incentives has been developed for depositors in the social sphere, business entities, foundations or individuals. Free Western Market Traditions Encourage Philanthropy. The social sphere in Ukraine, like no other, needs organized financing from extrabudgetary funds. For a clearer and more professional organization of recruiting sponsors and donors, there are first-rate professionals who can replenish the budget of NGOs.

In a market economy, civil society and social initiatives, philanthropy has become a major boon in the form of patronage, sponsorship and support through the provision of grants, donations, material, information resources and more. The proliferation of charity and its form of organized activity has led to the emergence of fundraising, as a science of planning and streamlining actions that will help organized actions for patrons and beneficiaries.

Today, fundraising is not sufficiently developed in our country, but in spite of this it has certain prospects. Due to the growing role of civil society organizations, which are able to help the state in solving social problems, it contributes to the development of fundraising in Ukraine.

Today the dynamics of fundraising development in Ukraine is noticeably fast and effective. An important factor in the acceleration of this process is the highly qualified training of specialists in this field of activity, who will have the appropriate knowledge, skills.

Keywords: fundraising, non-profit organizations, technology of social work.

Юлия Шатило, канд. психол. наук, доц.?

Олександра Громова, студ.

Национальный авиационный университет, Киев, Украина

\section{РАЗВИТИЕ ФАНДРАЙЗИНГА КАК ТЕХНОЛОГИИ СОЦИАЛЬНОЙ РАБОТЫ В УКРАИНЕ}

Освещено теоретический анализ научной литературы по проблемам использования фандрайзинга как технологии социальной работы в современной Украине. Неприбыльные организации фактически выполняют функцию социальных посредников-реализаторов социальных идей и программ, то есть они действуют между государством, коммерческими фирмами и гражданами. Это все свидетельствует о важности всестороннего развития данного сектора экономики и для государства, и для бизнеса, и для общества.

Ключевые слова: фандрайзине, неприбыльные организации, технология социальной работы.

Bulletin of Taras Shevchenko National University of Kyiv. Series "Psychology". № 1(10), pp. 109-112 (2019) УДК 159.922: 044.332

DOI: https://doi.org/10.17721/BSP.2019.1(10).28
ISSN $1728-3817$

(C) Taras Shevchenko National University of Kyiv, Publishing Center "Kyiv University", 2019

Світлана Шевченко, канд. психол. наук, доц.

\section{КЛЮЧОВІ АСПЕКТИ ДОСЛІДЖЕННЯ ПСИХОФІЗІОЛОГІЧНОЇ АДАПТАЦІЇ ПЕРШОКУРСНИКІВ}

Здійснено науковий аналіз та експериментальне дослідження ключових аспектів психофізіологічної адаптації першокурсників. Визначено рівні адаптивних і комунікативних здібностей, нервово-психічної стійкості та моральної нормативності, показники психофізіологічної адаптації й основні ознаки, які вказують на джерела дезадаптації. Виокремлено критерії психофізіологічної адаптації (стан здоров'я, настрій, тривожність, ступінь стомлюваності, активність поведінки), сформульовано перспективи подальших досліджень.

Ключові слова: психофізіологічна адаптація, ознаки дезадаптація, адаптивні можливості, першокурсники.

Постановка наукової проблеми та її значення. У сучасному суспільстві відбувається закономірна зміна концептуальних напрямів української психології. Цей процес супроводжується переорієнтацією освітнього середовища, яке ставить високі вимоги до студентської молоді тому, що саме від неї залежить, яким буде майбутнє, якими темпами відбуватиметься прогрес суспільства та розвиток людства в цілому. Однією 3 найбільш значущих сфер навчання молодої людини постає процес її психофрізіологічної адаптації, який супроводжується постійним напруженням інтелектуальних, емоційних та вольових функцій, виникненням труднощів адаптації та емоційно-стресових ситуацій [7].

У нашому дослідженні ми зосередилися на вивченні особливостей психофізіологічної адаптації першокурсників до вищої школи. У зв'язку з цим, розгляд та вивчення зазначеної проблеми доцільно починати насамперед із конкретизації самого поняття адаптації та визначення часового проміжку адаптаційного періоду, оскільки думки різних авторів стосовно цього принципово різняться між собою. Окреслюючи часові кордони адаптаційного періоду першокурсників, у нашому дослідженні ми підтримуємося позиції К. О. Сантросяна, який виокремлює три етапи у процесі адаптації першокурсника стосовно психофрізіологічних реакцій, динаміки емоційних станів, реакцій здобувачів на стресові соціальні умови. Підтримуючи цю думку, В. О. Лефтеров виділив декілька головних етапів адаптаційного процесу. Перший ("гострий етап адаптації") спостерігається на початку навчального року та характеризується поганим функціональним станом першокурсника (втомою від складання випускних і вступних іспитів, емоційною напругою, спричинену новизною умов ЗВО). Другий етап включає екзаменаційний стрес першої сесії з емоційною напругою та погіршенням функціонального стану. Третій етап виявляється при подальших іспитах, коли індивідуально-психологічна напруга здобувача зменшується [4].

До того ж, ряд вітчизняних учених наголосили на тому, що найбільших випробувань зазнають здобувачі та їх адаптаційні ресурси якраз у перші місяці навчання, коли відбувається засвоєння нового способу життя та якісно інших форм відносин із педагогам щодо нового соціального й побутового середовища, що помітно знижує рівень пізнавальних та емоційно-вольових процесів [4-6, с. 8]. Отже, особливий інтерес становить діагностика психофрізіологічної адаптації у перший рік перебування здобувачів у закладі вищої освіти, а саме в гострий період адаптації, що, на нашу думку, триває упродовж першого семестру (від початку навчального року до першої екзаменаційно-залікової сесії в житті першокурсників). 
Аналіз досліджень свідчить про посилений інтерес науковців до вивчення поставленої проблеми. Вагомий внесок внесли такі дослідники, як Т.П.Браун,

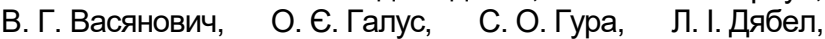
Н.В.Кузнецова, Г. П. Левківська, В. Ю. Лесовий, Д.Д.Наурузбаєв, Л. Л. Петльова, С. І. Сільверстов, В.П. Шпак, В. Є. Штифурак [3]. Багатоаспектність поняття "адаптація", його міжпредметне використання призвело до того, що серед науковців немає єдиної думки щодо його сутності. Так, одні автори називають адаптацію процесом "вживання", "звикання" та "інтеграцією" у навколишнє середовище, а інші, навпаки, - певним "бар'єром", що виникає в індивідів у нових для них умовах існування.

Поряд із цим, психофрізіологічна адаптація - це адаптація не тільки на рівні психічної сфери, а й на рівні пов'язаних із нею фрізіологічних функцій (Ц. П. Короленко); це "оптимальне співвідношення між психічними та фізіологічними адаптаційними процесами" (Ф. Б. Березін) [1]

Спираючись на системний підхід, О.М.Кокун запропонував таке визначення психофізіологічної адаптації: "...це процес, який зумовлений зміною у психофізіологічному стані людини під впливом дезадаптаційних фракторів, що потребує одночасної та узгодженої взаємодії функціональних підсистем на всіх рівнях цілісної системи, ... психофізіологічний стан з метою ефективного забезпечення діяльності в нових умовах" [2].

Однак на сьогодні не досліджено всебічно ключові аспекти психофрізіологічної адаптації першокурсників.

Мета і завдання статті передбачають науковий аналіз та експериментальне дослідження ключових аспектів психофрізіологічної адаптації першокурсників.

Виклад основного матеріалу й обґрунтування отриманих результатів дослідження. Вивчення наукової літератури засвідчило практичну значущість проблеми й необхідність здійснення експериментального дослідження. Для реалізації поставленої мети було проведено емпіричну діагностику першокурсників Мелітопольського державного педагогічного університету імені Богдана Хмельницького. Вибірку становили 285 здобувачів вищої освіти, що навчаються на першому курсі. У програму діагностики було включено такі методи діагностичного дослідження:
Методика "Багаторівневий особистісний опитувальник адаптивності" (авт. А. Г. Маклаков і С. В. Чермянін), яка спрямована на вимірювання рівня адаптивних і комунікативних здібностей, нервово-психічної стійкості та моральної нормативності здобувачів.

Методика "Опитувальник діагностики психофрізіологічної дезадаптації" (авт. О.Н.Родіна). Вона була спрямована на виявлення у першокурсників рівня їх дезадаптації та її основних ознак, які вказують на джерела дезадаптації. Критеріями психофрізіологічної адаптації вважаються стан здоров'я, настрій, тривожність, ступінь стомлюваності, активність поведінки. Дезадаптація може виникнути внаслідок короткочасних і сильних дій середовища на людину або під впливом менш інтенсивних, але тривалих факторів. Дезадаптація виявляється у погіршенні самопочуття, соматовегетативних симптомах, різних порушеннях інтелектуальної діяльності та взаємодії тощо.

Аналіз отриманих даних засвідчує (рис. 1), що у $51,23 \%$ із загальної кількості опитаних переважає низький рівень розвитку адаптивних здібностей. Ці здобувачі мають проблеми під час пристосування до вимог нового інтелектуально-освітнього середовища, не володіючи основними механізмами та способами його успішного освоєння, відчувають певний дискомфорт у ситуації здійснення розумової діяльності в цьому середовищі. У 35,09 \% першокурсників було виявлено задовільний рівень розвитку адаптивних здібностей. Успіх адаптації в них залежить від зовнішніх умов освітнього середовища, тобто вони, залежно від ситуації та її привабливості, для них особисто, можуть застосовувати або не застосовувати основні адаптаційні механізми. Лише 13,68 \% респондентів продемонстрували високий рівень розвитку адаптивних здібностей, виявили стійкі резистентні характеристики індивідуальнотипологічного та особистісного рівня індивідуальності, які забезпечують спроможність успішно адаптуватись до різноманітних вимог нового освітнього середовища, доволі легко та адекватно орієнтуватися в новій ситуації, швидко обирати стратегію своєї поведінки та соціалізації, що виявляється в застосуванні певних пристосувальних механізмах в умовах навчання у закладі вищої освіти.

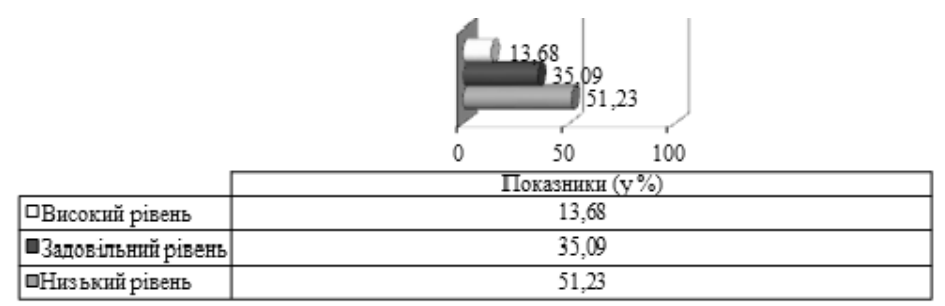

Рис. 1. Рівень розвитку адаптивних здібностей першокурсників ( $=285)$

Аналіз результатів рівня розвитку нервово-психічноі стійкості визначив (рис. 2), що у $58,95 \%$ із загальної кількості досліджених домінує низький рівень нервовопсихічної стійкості. Це свідчить про те, що вони менш витривалі в ситуації нового освітнього середовища та менш готові до впливу різного роду несприятливих фракторів (зростання розумового навантаження та вимог щодо його опрацювання, зміна звичної ситуації навчан- ня), не мають навичок поведінкового регулювання. Подібні вияви можуть бути вираженням захисних механізмів у період адаптації. Для групи першокурсників, у яких виявлено високі показники нервово-психічної стійкості $(41,05 \%)$, характерні високий рівень поведінкового регулювання та більш реальне сприйняття дійсності, вони готові протистояти новим впливам та ситуаціям.

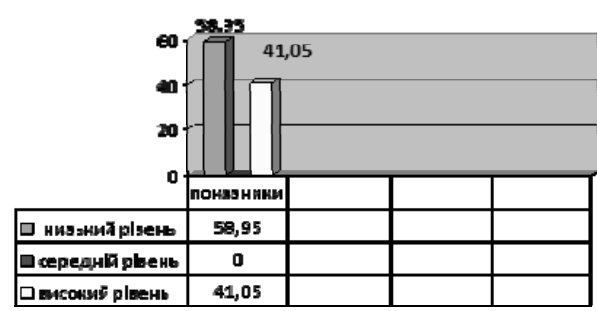

Рис. 2. Рівень розвитку нервово-психічної стійкості першокурсників ( $\mathrm{n}=285)$ 
Після обробки даних установлено два рівня розвитку комунікативних здібностей першокурсників(рис. 3). У $57,54 \%$ опитаних переважає високий рівень розвитку комунікативних здібностей, які забезпечують ефективну взаємодію та взаєморозуміння в процесі спілкування та виконання спільної інтелектуальної діяльності. Ці здобувачі не конфліктні, доволі легко встановлюють контакти 3 оточуючими, відкриті для спілкування і нових взаємин. У $42,46 \%$ із загальної кількості досліджених виявлено низькі показники цих здібностей. Це дає підстави констатувати, що вони мають різного роду проблеми в налагодженні контактів із оточуючими, виявляючи замкнутість або ж агресивність у взаєминах, спілкуванні та здійснюючи спільну інтелектуальну діяльність.
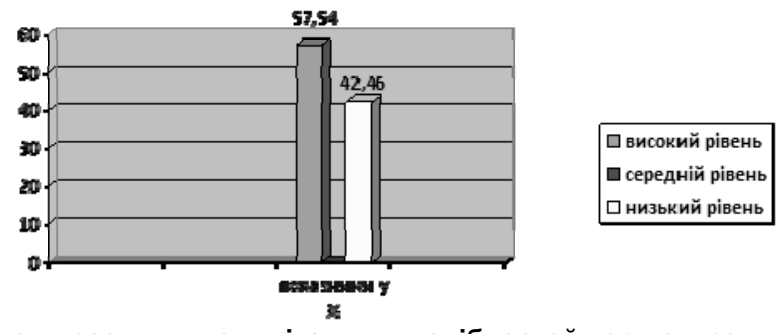

Рис. 3. Рівень розвитку комунікативних здібностей першокурсників $(\mathrm{n}=\mathbf{2 8 5})$

Аналізуючи показники моральної нормативності першокурсників виявлено такі результати (рис. 4). У 75,09\% респондентів визначено високий рівень моральної нормативності. Вони реально оцінюють свою роль у колективі, взаєминах, орієнтуючись на дотримання загальноприйнятих норм поведінки, адекватно сприймають запропоновану їм нову соціальну роль та нові вимоги інтелектуально-освітнього середовища. Поряд із тим, у 24,91\% із загальної кількості опитаних виявлено низький рівень цієї здатності, вони не завжди можуть чітко оцінити своє місце та роль у колективі, не прагнуть сприймати та дотримуватися загальноприйнятих морально-етичних норм поведінки й вимог нового освітнього середовища.

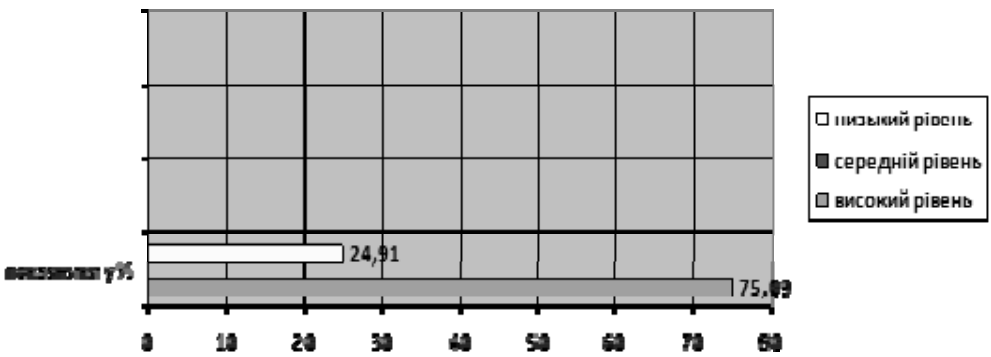

Рис. 4. Рівень розвитку моральної нормативності першокурсників $(n=285)$

Після обробки даних було отримано показники рівня психофрізіологічної дезадаптації першокурсників. Отже, у $68,07 \%$ респондентів виявлено помірний (середній) рівень дезадаптації. Вони мають час від часу певні труднощі, які пов'язані зі зміною форм, методів навчання й оцінювання, відчувають певний дискомфорт у ситуації нового освітнього середовища, що може виявлятися в незначному зниженні продуктивності їх розумової роботи. Разом із тим визначено, що у 16,49\% першокурсників чітко виражений рівень дезадаптації. Їм властива неможливість пристосування до характеру, змісту, умов і організації навчального процесу, а також можливості вироблення навичок самостійності у навчальній та розумовій роботі. У 12,98 \% загальної кількості опитаних респондентів виявлено низький рівень дезадаптації, що вказує на відсутність сильних переживань, пов'язаних із недостатньою соціалізацією у нових умовах, соціально неприйнятними установками особистості, різкою зміною умов існування, розривом важливих соціальних відносин тощо. Також робота показала, що $2,46 \%$ першокурсників демонструють високий рівень дезадаптації, що вимагає вживання певних заходів. Для них процес навчання у ЗВО породжує певний страх і згодом може перерости у кризову ситуацію. В них спостерігається зниження комунікабельності, емоційної стійкості, самоконтролю, соціальної сміливості, з'являється почуття неповноцінності у стосунках із товаришами, учителями, батьками, а в поведінці в цілому - надмірна сором'язливість. Унаслідок цього знижується успішність, спостерігається недостатня увага й зосередженість на заняттях, а також утрата інтересу до навчання та ЗВО.

Крім цього, аналіз окремих ознак дав можливість визначити основні джерела психофрізіологічної дезадаптації першокурсників(табл. 1).

Джерела психофізіологічної дезадаптації першокурсників $(\mathbf{n}=\mathbf{2 8 5})$

Таблиця 1

\begin{tabular}{|l|c|}
\hline \multicolumn{1}{|c|}{ Перелік джерел психофізіологічної дезадаптації першокурсників } & Ступінь вияву (показники у \%) \\
\hline Особливості окремих психічних процесів & 18,59 \\
\hline Зниження загальної активності & 16,49 \\
\hline Зниження мотивації до діяльності & 16,18 \\
\hline Відчуття постійної втоми & 15,09 \\
\hline Порушення циклу "сон - бадьорість" & 15,09 \\
\hline Особливості соціальної взаємодії & 13,30 \\
\hline Соматовегетативні порушення & 3,16 \\
\hline Емоційні порушення & 2,10 \\
\hline
\end{tabular}

Як видно з табл. 1, найчастіше першокурсники мають певні труднощі у пристосуванні до нового освітнього середовища та переживають через погіршення самопочуття, зокрема у зв'язку з особливостями окремих психічних процесів (18,59\%), що виявляється у змінах способах сприйняття, переробки та запам'ятовування нової інфрормації. У них спострегається зниження загальної активності (16,49 \%) і мотивації до будь-якої 
діяльності (16,18 \%), що може бути пов'язане із невпевненістю у правильності обраної професії чи відсутністю навичок конструктивного подолання проблем, із якими вони стикаються. Виявлено також, що для першокурсників характерне відчуття постійної втоми $(15,09 \%)$ та зниження й порушення циклу "сон бадьорість" (15,09\%). Спостерігається зниження продуктивності розумової діяльності, небажання та нездатність виконувати ії, млявість і пасивність при виконанні інтелектуальних завдань. Для 13,30\% першокурсників дезадаптація пов'язана з особливостями соціальної взаємодії. Вони мають певні труднощі в налагодженні нових контактів, необхідності соціальної взаємодії (як правило, ці студенти сором'язливі, некомунікабельні та менш контактні). Найменші показники щодо джерел і вияву психофізіологічної дезадаптації виявлені за емоційними (3,16 \%) та соматовегетативними порушеннями $(2,10 \%)$, що вказує на наявність незначних проблем у змінах емоційної сфери та здоров'я здобувачів.

Висновки та перспективи. Отже, за результатами проведеної роботи встановлено, у більшості першокурсників спостерігаються високі показники розвитку комунікативних здібностей і моральної нормативності. Вони реально оцінюють свою роль у колективі, взаєминах, орієнтуючись на дотримання загальноприйнятих норм поведінки. Першокурсникі здатні до прийняття інших людей такими, якими вони є, поважають їх своєрідність і право бути собою. Розвиненість подібної здібності характеризує їх як зрілу особистість. Було виявлено високі показники за шкалою оптимістичності та високу здатність до соматичної регуляції. Крім того, у молоді виявлено помірний (середній) рівень психофізіологічної дезадаптації. Вони мають час від часу певні труднощі, які пов'язані зі зміною форм, методів навчання й оцінювання, які характерні для загальноосвітньої школи, а найчастіше проблеми виникають у них через погіршення самопочуття, а саме: у зв'язку 3 особливостями окремих психічних процесів першокурсників, через зниження їх загальної активності та мотивації до будь-якої діяльності. У першокурсників переважає низький рівень розвитку адаптивних здібностей та нервово-психічної стійкості. Ці дані вказують на необхідність розробки системи заходів щодо актуаліза- ції адаптаційних можливостей першокурсників. Цей напрям визначений нами як перспективний вектор подальших досліджень цієї проблеми.

Список використаних джерел

1. Березин Ф.Б. Психическая и психофизиологическая адаптация человека / Ф. Б. Березин. - Л., 1988.

2. Кокун О. М. Психофізіологія : навч. посіб. / О. М. Кокун. - К. : Центр навч. літератури, 2006. - 184 с

3. Левківська Г.П. Адаптація першокурсників в умовах вищого закладу освіти : навч. посіб. / Г. П. Левківська, В. Є. Сорочинська, В. С. Штифурак. K., 2001. -128 c.

4. Лестеров В. О. Психологічні аспекти проблеми адаптації курсантів до навчального простору [Електронний ресурс] / Василь Олександрович Лефтеров. - Режим доступу: http://www.nbuv.gov.ua/ejournals/ Vnadps/2010_4/10lvodnp.pdf.

5. Литвинова Л. В. Причини психологічної дезадаптації студентівпершокурсників / Лариса Володимирівна Литвинова // Проблеми загальної та педагогічної психології: зб. наук. пр. Ін-ту психології
ім. Г. С. Костюка АПН України / за ред. С. Д. Максименка. - К., 2000. ім. Г. С. Костюка АПН Укра
Т. ІІ. - Ч. 6. - С. $300-304$

6. Семиченко В. А. Психические состояния: модульный курс для преподавателей и студентов / Валентина Анатольевна Семиченко. - К. : Магістр-S, 1998. - 207 с

7. Шевченко С.В. Психолого-педагогічні умови підвищення розумової працездатності студентів-першокурсників в адаптаційний період : дис канд. психол. наук: 19.00.07, Нац. пед. ун-т ім. М. П. Драгоманова. - К., 2015. -200 c

\section{References}

1. Berezyn, F. B. (1988) Psykhycheskaia y psykhofyzyolohycheskaia adaptatsyia cheloveka // Mental and psychophysiological human adaptation [in Russian].

2. Kokun, O. M. (2006) Psykhofiziolohiia [Psychophysiology]. - Kyiv : Tsentr navchalnoi literatury [in Ukrainian].

3. Levkivska, H. P., Sorochynska, V. I., Shtyfurak, V. S. (2001) Adaptatsiia pershokursnykiv $\mathrm{v}$ umovakh vyshchoho zakladu osvity // Adaptation of first-year students in higher education institutions. -Kyiv [in Ukrainian]

4. Lefterov, V. O. Psykholohichni aspekty problemy adaptatsii kursantiv do navchalnoho prostoru [Elektronnyi resurs] // Psychological aspects of the problem of adaptation of cadets to the educational space [in Ukrainian]

5. Lytvynova, L. V. (2000) Prychyny psykholohichnoi dezadaptatsii studentiv-pershokursnykiv [Reasons for psychological maladaptation of freshmen students] // Problemy zahalnoi ta pedahohichnoi psykholohii: zb. nauk. pr. In-tu psykholohii im. H.S. Kostiuka APN Ukrainy. S. D. Maksymenka [Ed.] - Kyiv, T. II, ch. 6, 300-304 [in Ukrainian].

6. Semychenko, V. A. (1998) Psykhycheskye sostoianyia: modulni kurs dlia prepodavatelei y studentov [Mental states: a modular course for teachers and students]. - Kyiv : Mahistr-S [in Russian]

7. Shevchenko, S. V. (2015) Psykholoho-pedahohichni umovy pidvyshchennia rozumovoi pratsezdatnosti studentiv-pershokursnykiv $v$ adaptatsiinyi period [Psychological-pedagogical conditions for improving the mental capacity of freshmen students in the adaptation period] / Dysertatsiia ... kand. psykhol. nauk : 19.00.07, Nats. ped. un-t im. M. P. Drahomanova. - Kyiv [in Ukrainian]

Надійшла до редколегії 01.07.19

Svitlana Shevchenko, PhD, Assoc. Prof.

Bogdan Khmelnitsky State Pedagogical University of Melitopol, Melitopol, Ukraine

\section{KEY ASPECTS OF THE STUDY OF PSYCHOPHYSIOLOGICAL ADAPTATION OF FIRST-YEAR STUDENTS}

The article considers and studies the problem of psychophysiological adaptation of freshmen through the concretization of the very concept of adaptation and determination of the time period of the adaptation period. Moreover, carried out a scientific analysis and experimental study of key aspects of psycho-physiological adaptation of first-year students. The levels of adaptive and communicative abilities, neuropsychic stability and moral norm, indicators of psychophysiological adaptation and the main features that indicate the sources of maladaptation have been determined. The criteria for psychophysiological adaptation (state of health, mood, anxiety, fatigue, activity behavior) are highlighted, and prospects for further research are formulated.

According to the results of the work it was found that most freshmen have high rates of development of communicative abilities and moral normativity. They really assess their role in the team, in relationships, focusing on compliance with generally accepted norms of behavior. Freshmen are capable of accepting other people as they are, respect their originality and the right to be themselves. The development of such an ability characterizes them as a mature personality.

High optimism score and high ability for somatic regulation were found. In addition, a moderate (average) level of psychophysiological maladaptation was found in young people. From time to time, they have certain difficulties associated with changes in the forms, teaching and assessment methods that are characteristic of a comprehensive school, and most often they experience problems due to a deterioration in wellbeing, namely, due to the characteristics of individual mental processes of freshmen, a decrease their overall activity and a decrease in motivation for any activity. Freshmen are dominated by a low level of development of adaptive abilities and neuropsychic stability.

The data obtained indicate the need to develop a system of measures to update the adaptive capabilities of freshmen. We identified this direction as a promising vector for further studies of this problem.

Keywords: psychophysiological adaptation, signs of maladjustment, adaptive capabilities, first-year students.

Светлана Шевченко, канд. психол. наук, доц.

Мелитопольский государственный педагогический университет имени Богдана Хмельницкого, Мелитополь, Украина

\section{КЛЮЧЕВЫЕ АСПЕКТЫ ИССЛЕДОВАНИЯ ПСИХОФИЗИОЛОГИЧЕСКОЙ АДАПТАЦИИ ПЕРВОКУРСНИКОВ}

Осуществлен научный анализ и экспериментальное исследование ключевых аспектов психофизиологической адаптации первокурсников. Определены уровни адаптивных и коммуникативных способностей, нервно-психической устойчивости и моральной нормативности, показатели психофизиологической адаптации и основные признаки, которые указывают на источники дезадаптации. Выделены критерии психофизиологической адаптации (состояние здоровья, настроение, тревожность, степень утомляемости, активность поведения), сформулированы перспективы дальнейших исследований. 